\title{
Cone beam computed tomography evaluation of ponticulus posticus in patients with cleft lip and palate: a retrospective radio-anatomic study
}

\author{
i.Ş. Bayrakdar ${ }^{1}$, Y. Yasa², Ş.B. Duman³ ${ }^{3}$, U.E. Karaturgut ${ }^{4}$, A. Ocak ${ }^{5}$, S. Günen Yılmaz ${ }^{6}$ \\ ${ }^{1}$ Department of Oral and Maxillofacial Radiology, Faculty of Dentistry, Eskisehir Osmangazi University, Eskisehir, Turkey \\ 2Department of Oral and Maxillofacial Radiology, Faculty of Dentistry, Ordu University, Ordu, Turkey \\ ${ }^{3}$ Department of Oral and Maxillofacial Radiology, Faculty of Dentistry, Inönü University, Malatya, Turkey \\ ${ }^{4}$ Department of Oral and Maxillofacial Radiology, Faculty of Dentistry, Suleyman Demirel University, Isparta, Turkey \\ ${ }^{5}$ Department of Oral and Maxillofacial Radiology, Faculty of Dentistry, Ataturk University, Erzurum, Turkey \\ ${ }^{6}$ Department of Oral and Maxillofacial Radiology, Faculty of Dentistry, Akdeniz University, Antalya, Turkey
}

[Received: 5 July 2017; Accepted: 4 August 2017]

Background: Ponticulus posticus (PP) is an abnormal bony bridge on the atlas. It plays a significant role in patients undergoing $C 1$ lateral mass screw procedure. Patients with cleft lip and palate (CLP) have higher risk than patients in general population for the appearance of cervical vertebral anomalies. The purpose of the this study was twofold: to determine the prevalence and characteristics of PP in patients with CLP, and to compare the findings with patients in general population using cone beam computed tomography.

Materials and methods: Cone beam computed tomography images from 54 individuals who had undergone surgical repair of cleft lip and/or palate were analysed as the study group. For comparison purposes a control group was randomly selected from 108 patients and matched with the CLP subjects.

Results: Although 12 of the 54 (22.3\%) patients with surgically repaired cleft lip and/or palate in the study group were identified to have PP, only 10 of the 108 (9.2\%) patients in the control group had PP. The distribution of the presence of PP between the groups was statistically significant.

Conclusions: Ponticulus posticus is an important anomaly and the presence of $P P$ is important for patients. PP can have clinical significance in cervical spine surgery as this study has indicated that the likelihood of encountering PP is higher in patients with CLP. We suggest that PP should be taken into account prior to cervical vertebral surgery in patients with CLP. (Folia Morphol 2018; 77, 1: 72-78)

Key words: cleft lip and palate, ponticulus posticus, foramen arcuale, cone beam computed tomography

\section{INTRODUCTION}

Ponticulus posticus (PP) is an abnormal bony bridge on the atlas. It arises from the posterior part of the superior articular process and the postero-lateral part of the superior margin of the posterior arch of atlas $[3,6,12]$. It surrounds the sulcus completely or partially for the passage of the vertebral artery from the transverse foramen into the foramen magnum. Besides the vertebral artery, PP contains suboccipital nerve and it is related to dura by way of atlanto-

Address for correspondence: i.Ş. Bayrakdar, Assistant Professor, DDS, PhD, Department of Dentomaxillofacial Radiology, Faculty of Dentistry, Eskişehir Osmangazi University, Eskişehir, Turkey, tel:+902222391203, fax: +902462370607, e-mail: ibrahimsevkibayrakdar@gmail.com 
occipital membrane. In the literature, it has been associated with different conditions such as cervical pain, headache, hearing loss, vertigo and vertebrobasilar insufficiency [31]. Furthermore, PP is an important subject for the treatment of atlantoaxial instability. Atlantoaxial instability is characterised by excessive movement between the atlas and the axis that can result in clinical signs such as balance problems, blurred vision, vertigo, and headache. The popular treatment of the atlantoaxial instability is the lateral mass screw fixation for the stabilisation of the atlas $[3,30]$. PP plays a significant role in patients undergoing $\mathrm{C} 1$ lateral mass screw (C1LMS) procedure. Because this region contains critical anatomical structures such as the major occipital nerve and epidural venous plexus, surgeons should be very meticulous as they apply screws during C1LMS procedure. A broad posterior arch of the atlas is the best condition to apply this procedure. In patients with PP, it can be misidentified as a broad posterior arch and the screw can be inserted into the PP. This can cause critical complications $[22,24,40]$.

Cleft lip and palate (CLP) are the most common abnormalities among all the birth defects. CLP results in many complications including feeding, speech, hearing and psychological development. Patients with CLP have higher risk than patients in general population for the appearance of cervical vertebral anomalies $[7,9,24,25,38]$. The purpose of the this study was twofold: to determine of the prevalence and characteristics of PP in patients with CLP, and to compare the findings with patients in general population using cone beam computed tomography (CBCT).

\section{MATERIALS AND METHODS}

\section{Study population}

We designed a retrospective study composed of the CBCT images that were obtained at the Dentistry Faculty of Inönü University in Malatya, Turkey. All of the patients had been referred for the diagnosis and treatment planning of different problems involving the dento-maxillofacial region. CBCT images from 54 individuals ( 31 males and 23 females, with an age range of 7-55 years) who had undergone surgical repair of CLP (unilateral or bilateral) were analysed as the study group. For comparison purposes a control group was randomly selected from 108 patients who were admitted to the radiology department for CBCT imaging and matched with the CLP subjects (49 females and 59 males, with an age range of 7-56 years). The exclusion criteria applied to both groups were the poor image quality and the presence of craniofacial syndromes.

The Clinical Research Ethics Committee of Süleyman Demirel University, Medicine Faculty approved this study with decision no: 216 , dated: 21.12.2016.

\section{Imaging procedure}

The CBCT images were obtained in a standard supine position (scanning time: 14-18 s, collimation height: $13 \mathrm{~cm}$ and voxel size: $0.3 \mathrm{~mm}^{3}$ ) using the same device (NewTom 5G, Quantitative Radiology [QR] Verona, Italy). The QR-NNT version 2.21 programme was used for evaluation.

\section{Evaluation of the CBCT images}

The CBCT images were examined for the PP. Threedimensional (3D) images were obtained and the direction of the PP was determined on 3D images. Subsequently, the direction of the PP was adjusted on the axial images using the multiplanar rendering mode of the QR-NNT software. Sagittal sectional images were used to detect the PP because of the direction of the PP on the atlas. In this study, a complete PP was defined as one steady bridge extending from the posterior facet of the lateral mass to the anterior facet of the posterior tubercle. A partial PP was considered if the bridge did not extend completely from the posterior lateral mass to the posterior tubercle.

\section{Statistical analysis}

Statistical analyses were performed using SPSS version 20.0 for Windows (SPSS Inc., Chicago, Illinois, USA). Kolmogorov-Smirnov statistics were used for the normality test. The $\chi^{2}$ test was used to evaluate differences in the presence of PP between the groups. Mann Whitney $\mathrm{U}$ test was used to compare chronological ages between the groups.

\section{RESULTS}

In this research, two groups, a study and a control group, were constituted to evaluate the PP. The study group comprised 54 subjects with surgically repaired CLP and the control group comprised 108 subjects who were randomly selected. The study group comprised 31 males and 23 females with an average age of $18.17 \pm 9.17$ (range: $7-55$ years) and the control group comprised 49 females and 59 males with an average age of $20.54 \pm 11.37$ (range: $7-56$ years). Table 1 shows that gender distribution and chrono- 
Table 1. Frequency and distribution of ponticulus posticus (PP) (complete and partial) and demographic variables between groups

\begin{tabular}{lccccc}
\hline & PP absent & PP present & Total & Female/male & Age, mean (SD) \\
\hline Cleft group & $42(77.7 \%)$ & $12(22.3 \%)$ & $54(33.3 \%)$ & $23 / 31$ & $18.17(9.12)$ \\
Normal & $98(90.8 \%)$ & $10(9.2 \%)$ & $108(66.7 \%)$ & $44 / 54$ & $20.54(11.37)$ \\
Total & 140 & 22 & $172(100 \%)$ & $67 / 85$ & $19.75(10.70)$ \\
P & $0.023^{\mathrm{a}}$ & & & $0.253^{\mathrm{a}}$ & $0.185^{\mathrm{b}}$ \\
\hline
\end{tabular}

aResults of $\chi^{2}$ test; ${ }^{b}$ Results of Mann Whitney $U$ test

Table 2. The distribution of varied appearance of ponticulus posticus in our study

\begin{tabular}{|c|c|c|c|c|c|c|}
\hline & \multicolumn{3}{|c|}{ Cleft-palate group } & \multicolumn{3}{|c|}{ Control group } \\
\hline & Female & Male & Total & Female & Male & Total \\
\hline Bilateral absent & $14(60.9 \%)$ & $28(90.3 \%)$ & $42(77.8 \%)$ & $44(89.2 \%)$ & $54(91.5 \%)$ & $98(91 \%)$ \\
\hline Bilateral complete & $2(8.7 \%)$ & $0(0 \%)$ & $2(3.7 \%)$ & $1(2 \%)$ & $1(1.7 \%)$ & $2(1.8 \%)$ \\
\hline Bilateral partial & $0(0 \%)$ & $2(6.5 \%)$ & $2(3.7 \%)$ & $1(2 \%)$ & $1(1.7 \%)$ & $2(1.8 \%)$ \\
\hline Right absent-left complete & $0(0 \%)$ & $0(0 \%)$ & $0(0 \%)$ & $0(0 \%)$ & $0(0 \%)$ & $0(0 \%)$ \\
\hline Right absent-left partial & $2(8.7 \%)$ & $1(3.2 \%)$ & $3(5.6 \%)$ & $0(0 \%)$ & $0(0 \%)$ & $0(0 \%)$ \\
\hline Right complete-left absent & $0(0 \%)$ & $0(0 \%)$ & $0(0 \%)$ & $0(0 \%)$ & $0(0 \%)$ & $0(0 \%)$ \\
\hline Right complete-left partial & $0(0 \%)$ & $0(0 \%)$ & $0(0 \%)$ & $1(2 \%)$ & $1(1.7 \%)$ & $2(1.8 \%)$ \\
\hline Right partial-left absent & $3(13 \%)$ & $0(0 \%)$ & $3(5.6 \%)$ & $2(4.1 \%)$ & $0(0 \%)$ & $2(1.8 \%)$ \\
\hline Right partial-left complete & $2(8.7 \%)$ & $0(0 \%)$ & $2(3.7 \%)$ & $0(0 \%)$ & $2(3.4 \%)$ & $2(1.8 \%)$ \\
\hline Total & 23 & 31 & 54 & 49 & 59 & 108 \\
\hline
\end{tabular}

logical ages were similar between the groups (Mann Whitney $U$ test and $\chi^{2}$ test, $p>0.05$ for both tests).

The presence of PP between the groups is shown in Table 1. Although 12 of the 54 (22.3\%) patients with surgically repaired CLP in the study group were identified to have PP, only 10 of the 108 (9.2\%) patients in the control group had PP. The distribution of the presence of PP between the groups was statistically significant $(p<0.001)$.

The distribution of varied appearance of PP in our study is shown in Table 2. Identified PP cases in the study group were as follows: bilateral complete in $2(3.7 \%)$ patients (Fig. 1A, B), bilateral partial in $2(3.7 \%)$ patients, right absent-left partial in $3(5.6 \%)$ patients (Fig. 2A, B), right partial-left absent in $3(5.6 \%)$ patients, and right partial-left complete in $2(3.7 \%)$ patients.

Identified PP cases in the control group were as follows: bilateral complete in $2(1.8 \%)$ patients, bilateral partial in 2 (1.8\%) patients, right completeleft partial in $2(1.8 \%)$ patients, right partial-left absent in $2(1.8 \%)$ patients, and right partial-left complete in $2(1.8 \%)$ patients. The prevalence rates of PP in the study and the control group are shown in Table 3.

\section{DISCUSSION}

Ponticulus posticus has become an important anomaly of the atlas vertebrae (Fig. 3). It could be considered a simple anatomical variation but it has been studied widely in the literature because of its important anatomical location and the involvement of critical structures. PP has been associated with different clinical situations including headaches, migraine, shoulder or arm pain, cervical pain syndrome, vertebrobasilar insufficiency and acute hearing loss [1-26]. The prevalence of PP was reported to be higher in patient with one narrow disc space. Takaaki et al. [37] and Sekerci et al. [29] reported that PP and the elongated styloid process may be related. Besides, PP was a frequent finding in nevoid basal cell carcinoma syndrome $[10,20]$.

Ponticulus posticus has become an important anomaly of the atlas, as the use of lateral mass screws for the fixation of the atlas has become more common for the treatment of atlanto-axial instability. If PP can be identified correctly, important 


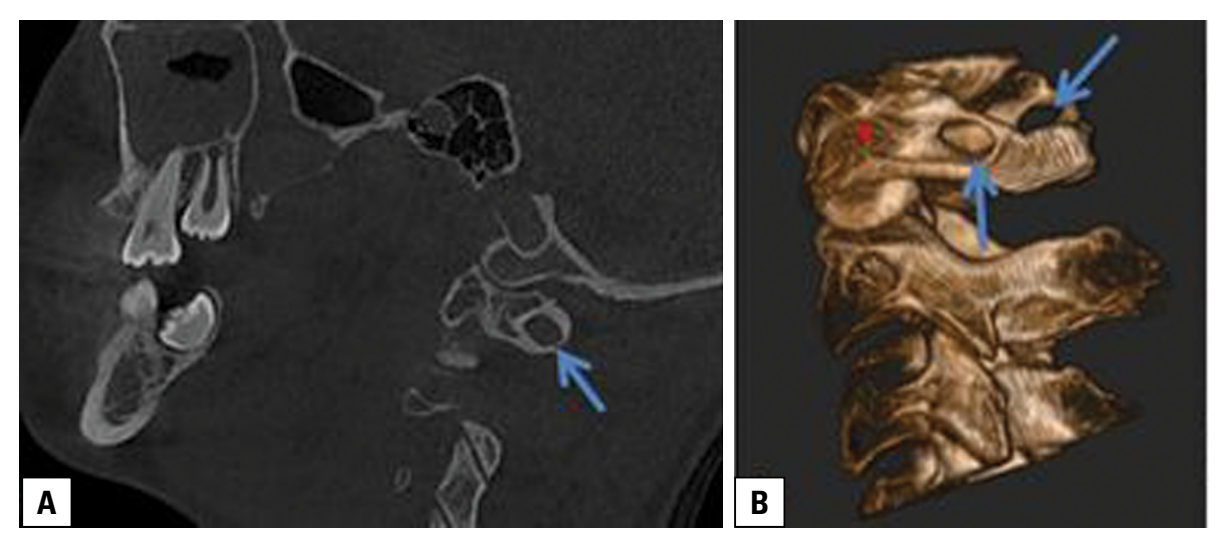

Figure 1. Bilateral complete ponticulus posticus on sagittal slices and three-dimensional (3D); A. Sagittal view; B. 3D image.
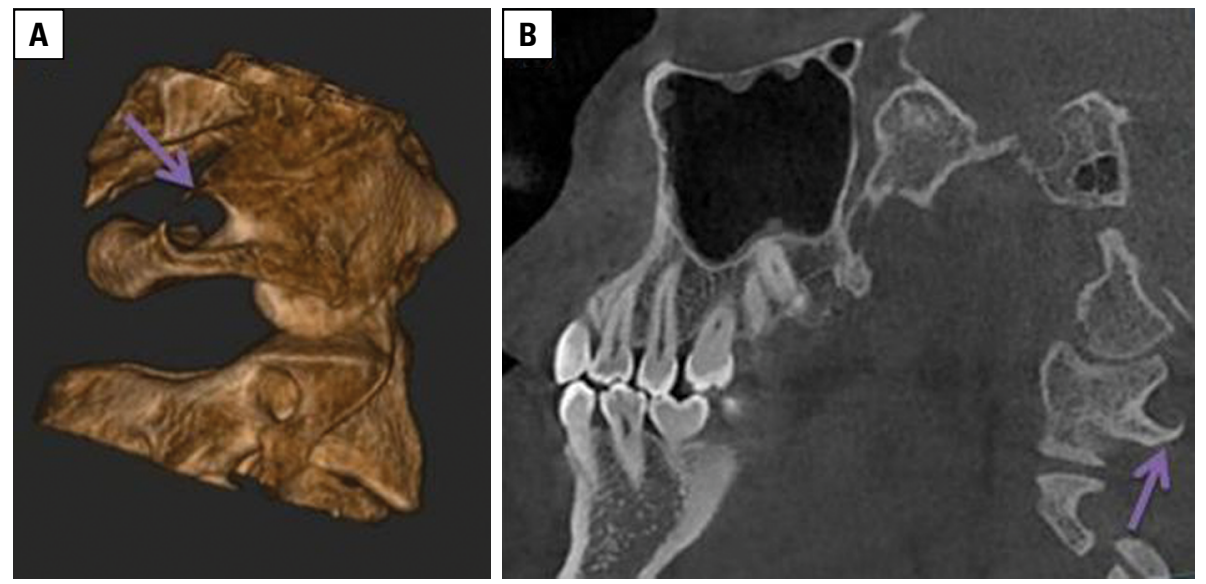

Figure 2. Partial ponticulus posticus on sagittal slices and three-dimensional (3D) image; A. 3D image; B. Sagittal view.

Table 3. The prevalence rates of ponticulus posticus in the cleft lip patients and the control group

\begin{tabular}{|c|c|c|c|c|c|c|}
\hline & \multicolumn{3}{|c|}{ Right } & \multicolumn{3}{|c|}{ Left } \\
\hline & Male & Female & Total & Male & Female & Total \\
\hline \multicolumn{7}{|c|}{ Cleft-palate group } \\
\hline Absent & $29(93.5 \%)$ & $16(69.6 \%)$ & 45 (83.3\%) & $28(90.3 \%)$ & 17 (73.9\%) & $45(83.3 \%)$ \\
\hline Complete & $0(0 \%)$ & $2(8.7 \%)$ & $2(3.7 \%)$ & $0(0 \%)$ & $4(17.4 \%)$ & $4(7.4 \%)$ \\
\hline Partial & $2(6.5 \%)$ & $5(21.7 \%)$ & $7(13 \%)$ & $3(9.7 \%)$ & $2(8.7 \%)$ & $5(9.3 \%)$ \\
\hline Total & $31(100 \%)$ & $23(100 \%)$ & $54(100 \%)$ & 31 & 23 & 54 \\
\hline \multicolumn{7}{|l|}{ Normal } \\
\hline Absent & $54(91.5 \%)$ & $44(89.8 \%)$ & $98(90.7 \%)$ & $54(91.5 \%)$ & 46 (93.9\%) & $100(92.6 \%)$ \\
\hline Complete & $2(3.4 \%)$ & $2(4.1 \%)$ & $4(3.7 \%)$ & $3(5.1 \%)$ & $1(2 \%)$ & $4(3.7 \%)$ \\
\hline Partial & $3(5.1 \%)$ & $3(6.1 \%)$ & $6(5.6 \%)$ & $2(3.4 \%)$ & $2(4.1 \%)$ & $4(3.7 \%)$ \\
\hline Total & 59 & 49 & 108 & 59 & 49 & 108 \\
\hline
\end{tabular}

complications arising due to ignoring this anomaly can be avoided in cervical spine surgery $[3,6,31]$. $3 \mathrm{D}$ images should be obtained preoperatively to establish the type, location, size, and shape of the
PP in order to design a personalised approach to C1 pedicle screw fixation and to avoid mistaking the PP for a widened dorsal arch of the atlas. It was not difficult to choose a right entry point and a right screw 

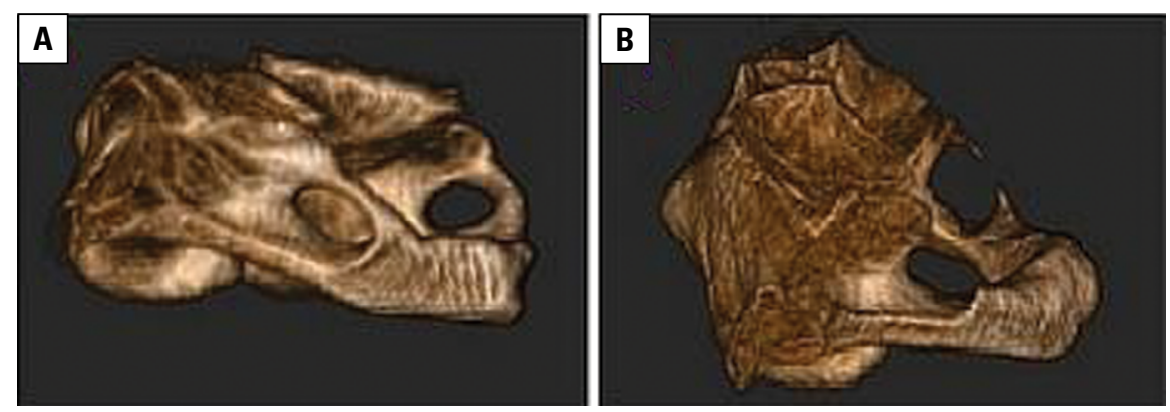

Figure 3. Three-dimensional images of ponticulus posticus on extracted images atlas vertebrae; A. Complete ponticulus posticus; B. Partial ponticulus posticus.

trajectory after careful evaluation of preoperative 3D images $[22,39,40]$.

The prevalence of PP has been found to be $1-46 \%$, using lateral cephalometric radiographs, CT, CBCT, cadaver or dried atlas specimens in different populations $[3,4,15,29]$. Meta-analysis studies conducted by Elliott and Tanweer [8] in 2014 and Pękala et al. [23] in 2017 reported the mean prevalence of PP. In the study of Elliott and Tanweer [8] it was 19\% for cadavers, $17 \%$ on CT images, $17 \%$ on lateral radiographs and $17 \%$ overall. Pękala et al. [23] reported that the overall prevalence of complete PP was $9.1 \%$ and partial PP was $13.6 \%$. Generally, a statistically significant difference has not been found between males and females with regard to the prevalence of PP. Sharma et al. [31] noted that the prevalence of complete PP of $4 \%$ was found in 858 Indian orthodontic patients aged 8-22 years, using lateral cephalometric radiographs. In this study, higher prevalence was found in males than females. Buyuk et al. [4] evaluated presence of PP in orthodontic population using $\mathrm{CBCT}$. They found that $43 \%$ of the patient had PP.

Development of the head and face is one of the most complex events during embryonic development. It is coordinated by a network of transcription factors and signalling molecules together with proteins regulating cell polarity and cell-cell interactions. Disturbance of this tightly controlled cascade can result in a facial cleft where the facial primordial ultimately fail to meet and fuse or form the appropriate structures. Collectively, craniofacial abnormalities are among the most common of all the birth defects. The most frequent of these are the $\operatorname{CLP}[7,13,19]$. When investigating the craniofacial dysmorphology, it is tempting to make an association between two or more defects and link them to a common embryonic event. The presence of associated anomalies in CLP has been proposed as a malformation spectrum and linked to a common embryologic factor based on a fault(s) at cellular level in which disruption of mesenchymal development may lead to abnormal migration, induction, and/or proliferation of embryonic tissues which can occur at sites distant from the palatal shelves, like the cervical spine. Numerous studies agree that patients with CLP exhibit a higher prevalence of cervical vertebral anomalies $[7,14,21,24,27]$.

The literature reported that there was a correlation between cervical vertebral morphology and cranio-facial malformations. Signalling during early embryogenesis between the notochord, para-axial mesoderm, the neural tube, and the neural crest can explain relations between the cervical vertebral column, the cranial base, and the craniofacial skeleton. Considering the fact that the cervical vertebrae and cranial base have common embryonic origin, and that the jaws are related to the cranial base, it may be speculated as a cause of association between the cervical vertebral anomalies and cranio-facial malformations [32-36]. Datana et al. [7] reported that the upper cervical anomalies were more common in the CLP group than the control group. The authors reported that the prevalence of cervical vertebral anomalies in the CLP group was $20.3 \%$ while it was $6.4 \%$ in the control group [9]. Perez and Chávez [24] studied the frequency of PP (complete and partial) in CLP patients and they stated that the frequency of complete PP was lower in the CLP group $(6.1 \%$ against $8.7 \%)$, whereas the frequency of partial PP was similar in both groups $(11.04 \%$ against $11.08 \%$ ) [24]. However, in our study, the prevalence of $\mathrm{PP}$ in the CLP group was higher than that in the control group. The discrepancy between the two studies can be explained by the fact that Perez and Chávez [24] used lateral cephalometric film in their study. In the present study, PP was evaluated by using CBCT. Exact characterisation of $\mathrm{PP}$ is possible only by $3 \mathrm{D}$ examination. The use of advanced imaging has been limited 
because of the cost, availability and radiation dose consideration. However, the introduction of CBCT provides opportunities to request multiplanar imaging. CBCT allows the creation of "real time" images not only in the axial plane but also two-dimensional images in the coronal, sagittal and even oblique or curved image planes $[6,28]$.

\section{CONCLUSIONS}

Ponticulus posticus is an important anomaly and the presence of PP is important for patients. PP can have clinical significance in cervical spine surgery as this study has indicated that the likelihood of encountering PP is higher in patients with CLP. We suggest that PP should be taken into account prior to cervical vertebral surgery in patients with CLP.

\section{REFERENCES}

1. Adisen MZ, Misirlioglu M. Prevalence of ponticulus posticus among patients with different dental malocclusions by digital lateral cephalogram: a comparative study. Surg Radiol Anat. 2017; 39(3): 293-297, doi: 10.1007/s00276016-1728-4, indexed in Pubmed: 27515304.

2. Afsharpour S, Hoiriis KT, Fox RB, et al. An anatomical study of arcuate foramen and its clinical implications: a case report. Chiropr Man Therap. 2016; 24: 4, doi: 10.1186/ s12998-016-0082-2, indexed in Pubmed: 26811743.

3. Bayrakdar IS, Miloglu O, Altun O, et al. Cone beam computed tomography imaging of ponticulus posticus: prevalence, characteristics, and a review of the literature. Oral Surg Oral Med Oral Pathol Oral Radiol. 2014; 118(6): e210-e219, doi: 10.1016/j.00oo.2014.09.014, indexed in Pubmed: 25457896.

4. Buyuk SK, Sekerci AE, Benkli YA, et al. A survey of ponticulus posticus: Radiological analysis of atlas in an orthodontic population based on cone-beam computed tomography. Niger J Clin Pract. 2017; 20(1): 106-110, doi: 10.4103/1119-3077.178916, indexed in Pubmed: 27958256.

5. Chen $\mathrm{CH}$, Chen YK, Wang CK. Prevalence of ponticuli posticus among patients referred for dental examinations by cone-beam CT. Spine J. 2015; 15(6): 1270-1276, doi: 10.1016/j.spinee.2015.02.031, indexed in Pubmed: 25720728.

6. Cho YJ. Radiological analysis of ponticulus posticus in Koreans. Yonsei Med J. 2009; 50(1): 45-49, doi: 10.3349/ ymj.2009.50.1.45, indexed in Pubmed: 19259347.

7. Datana S, Bhalla A, Kumar P, et al. Comparative evaluation of prevalence of upper cervical vertebrae anomalies in cleft lip/palate patients: a retrospective study. Int J Clin Pediatr Dent. 2014; 7(3): 168-171, doi: 10.5005/ jp-journals-10005-1258, indexed in Pubmed: 25709295.

8. Elliott RE, Tanweer $\mathrm{O}$. The prevalence of the ponticulus posticus (arcuate foramen) and its importance in the Goel-Harms procedure: meta-analysis and review of the literature. World Neurosurg. 2014; 82(1-2): e335-e343, doi: 10.1016/j.wneu.2013.09.014, indexed in Pubmed: 24055572.
9. Fakhim SA, Shahidi N, Lotfi A. Prevalence of associated anomalies in cleft lip and/or palate patients. Iran J Otorhinolaryngol. 2016; 28(85): 135-139, indexed in Pubmed: 27280100.

10. Friedrich RE. Ponticulus posticus is a frequent radiographic finding on lateral cephalograms in nevoid basal cell carcinoma syndrome (Gorlin-Goltz syndrome). Anticancer Res. 2014; 34(12): 7395-7399, indexed in Pubmed: 25503179.

11. Geist JR, Geist SMRY, Lin LM. A cone beam CT investigation of ponticulus posticus and lateralis in children and adolescents. Dentomaxillofac Radiol. 2014; 43(5): 20130451, doi: 10.1259/dmfr.20130451, indexed in Pubmed: 24785819.

12. Gibelli D, Cappella A, Cerutti E, et al. How frequent is ponticulus posticus in italian people? A lateral cephalometric study in an orthodontic population. Italian J Anat Embryol. 2015; 120(1): 34.

13. Hoenig JF, Schoener WF. Radiological survey of the cervical spine in cleft lip and palate. Dentomaxillofac Radiol. 1992; 21(1): 36-39, doi: 10.1259/dmfr.21.1.1397450, indexed in Pubmed: 1397450.

14. Horswell B. The incidence and relationship of cervical spine anomalies in patients with cleft lip and/or palate. J Oral Maxillofacial Surg. 1991; 49(7): 693-697, doi: 10.1016/ s0278-2391(10)80229-0.

15. Kim KH, Park KW, Manh TH, et al. Prevalence and morphologic features of ponticulus posticus in koreans: analysis of 312 radiographs and 225 three-dimensional CT scans. Asian Spine J. 2007; 1(1): 27-31, doi: 10.4184/ asj.2007.1.1.27, indexed in Pubmed: 20411149.

16. Koutsouraki E, Avdelidi E, Michmizos D, et al. Kimmerle's anomaly as a possible causative factor of chronic tensiontype headaches and neurosensory hearing loss: case report and literature review. Int J Neurosci. 2010; 120(3): 236-239, doi: 10.3109/00207451003597193, indexed in Pubmed: 20374094.

17. Krishnamurthy A, Nayak SR, Khan S, et al. Arcuate foramen of atlas: incidence, phylogenetic and clinical significance. Rom J Morphol Embryol. 2007; 48(3): 263-266, indexed in Pubmed: 17914493.

18. Krishnan P, Kartikueyan R, Patel SM, et al. Ponticulus posticus: An anatomical curiosity with clinical implications. Neurol India. 2015; 63(5): 805-806, doi: 10.4103/00283886.166555, indexed in Pubmed: 26448257.

19. Kuijpers M, Pazera A, Admiraal R, et al. Incidental findings on cone beam computed tomography scans in cleft lip and palate patients. Clinical Oral Investigations. 2013; 18(4): 1237-1244, doi: 10.1007/s00784-013-1095-z.

20. Leonardi R, Santarelli A, Barbato E, et al. Atlanto-occipital ligament calcification: a novel sign in nevoid basal cell carcinoma syndrome. Anticancer Res. 2010; 30(10): 4265-4267, indexed in Pubmed: 21036751.

21. Lima MC, Franco EJ, Janson G, et al. Prevalence of upper cervical vertebrae anomalies in patients with cleft lip and/ or palate and noncleft patients. Cleft Palate Craniofac J. 2009; 46(5): 481-486, doi: 10.1597/08-018.1, indexed in Pubmed: 20050375.

22. Mudit G, Srinivas K, Satheesha R. Retrospective analysis of ponticulus posticus in Indian orthodontic patients: a lateral cephalometric study. Ethiop J Health Sci. 2014; 24(4): 285-290, indexed in Pubmed: 25489191. 
23. Pękala PA, Henry BM, Pękala JR, et al. Prevalence of foramen arcuale and its clinical significance: a meta-analysis of 55,985 subjects. J Neurosurg Spine. 2017; 27(3): 276-290, doi: 10.3171/2017.1.SPINE161092, indexed in Pubmed: 28621616.

24. Pérez I, Chávez A. Frequency of ponticulus posticus, sella turcica bridge and clinoid enlargement in cleft lip and palate peruvian patients: a comparative study with non-cleft patients. Int J Morphol. 2015; 33(3): 895-901, doi: $10.4067 / \mathrm{s} 0717-95022015000300015$.

25. Rajion ZA, Townsend GC, Netherway DJ, et al. A three-dimensional computed tomographic analysis of the cervical spine in unoperated infants with cleft lip and palate. Cleft Palate Craniofac J. 2006; 43(5): 513-518, doi: 10.1597/05023, indexed in Pubmed: 16986980.

26. Sabir H, Kumbhare S, Rout P. Evaluation of ponticulus posticus on digital lateral cephalograms and cone beam computed tomography in patients with migraine and healthy individuals: a comparative study. Oral Surg Oral Med Oral Pathol Oral Radiol. 2014; 118(3): 348-354, doi: 10.1016/j.0000.2014.04.016, indexed in Pubmed: 25151589.

27. Sandham A. Cervical vertebral anomalies in cleft lip and palate. Cleft Palate J. 1986; 23(3): 206-214, indexed in Pubmed: 3524906.

28. Scarfe WC, Farman AG, Sukovic P. Clinical applications of cone-beam computed tomography in dental practice. J Can Dent Assoc. 2006; 72(1): 75-80, indexed in Pubmed: 16480609.

29. Sekerci $A E$, Soylu E, Arikan MP, et al. Is there a relationship between the presence of ponticulus posticus and elongated styloid process? Clin Imaging. 2015; 39(2): 220-224, doi: 10.1016/j.clinimag.2014.11.016, indexed in Pubmed: 25497077.

30. Sekerci AE, Soylu E, Arikan MP, et al. Prevalence and morphologic characteristics of ponticulus posticus: analysis using cone-beam computed tomography. J Chiropr Med. 2015; 14(3): 153-161, doi: 10.1016/j.jcm.2015.06.003, indexed in Pubmed: 26778928.

31. Sharma V, Chaudhary D, Mitra R. Prevalence of ponticulus posticus in Indian orthodontic patients. Den- tomaxillofac Radiol. 2010; 39(5): 277-283, doi: 10.1259/ dmfr/16271087, indexed in Pubmed: 20587651.

32. Sonnesen L, Kjaer I. Anomalies of the cervical vertebrae in patients with skeletal Class II malocclusion and horizontal maxillary overjet. Am J Orthod Dentofacial Orthop. 2008; 133(2): 188.e15-188.e20, doi: 10.1016/j. ajodo.2007.07.018, indexed in Pubmed: 18249281.

33. Sonnesen L, Kjaer I. Cervical column morphology in patients with skeletal open bite. Orthod Craniofac Res. 2008; 11(1): 17-23, doi: 10.1111/j.1601-6343.2008.00409.x, indexed in Pubmed: 18199076.

34. Sonnesen L, Kjaer I. Cervical vertebral body fusions in patients with skeletal deep bite. Eur J Orthod. 2007; 29(5): 464-470, doi: 10.1093/ejo/cjm043, indexed in Pubmed: 17693430.

35. Sonnesen L. Associations between the Cervical Vertebral Column and Craniofacial Morphology. Int J Dent. 2010; 2010: 295728, doi: $10.1155 / 2010 / 295728$, indexed in Pubmed: 20628592.

36. Sonnesen L, Petri N, Kjaer I, et al. Cervical column morphology in adult patients with obstructive sleep apnoea. Eur J Orthod. 2008; 30(5): 521-526, doi: 10.1093/ejo/cjn028, indexed in Pubmed: 18647950.

37. Takaaki M, Masanori O, Hidenori U, et al. Ponticulus ponticus: Its clinical significance. Acta Med Kinki Univ. 1979; 4: 427-430.

38. Uğar DA, Semb G. The prevalence of anomalies of the upper cervical vertebrae in subjects with cleft lip, cleft palate, or both. Cleft Palate Craniofac J. 2001; 38(5): 498-503, doi: 10.1597/1545-1569(2001)038<0498:TPOAOT>2.0. CO;2, indexed in Pubmed: 11522172.

39. Young JP, Young PH, Ackermann MJ, et al. The ponticulus posticus: implications for screw insertion into the first cervical lateral mass. J Bone Joint Surg Am. 2005; 87(11): 2495-2498, doi: 10.2106/JBJS.E.00184, indexed in Pubmed: 16264126.

40. Zhang XL, Huang DG, Wang XD, et al. The feasibility of inserting a $\mathrm{C} 1$ pedicle screw in patients with ponticulus posticus: a retrospective analysis of eleven patients. Eur Spine J. 2017; 26(4): 1058-1063, doi: 10.1007/s00586016-4589-y, indexed in Pubmed: 27246351. 